In accordance with the provisions of article viII, section 2, of the constitution of the Canadian Political Science Association, the nominating committee invites nominations for the office of President-Elect, Vice-President, six Members-AtLarge on the Board of Directors, and three Members of the Nominating Committee. Nominations should be in the hands of the Secretary-Treasurer (c/o Carleton University, Col. By Drive, Ottawa, Ont. K1S 5B6) before 15 January 1977.

Nominations should take into consideration the geographical distribution that would include the following regions: the Atlantic provinces, Quebec, Ontario, the prairie provinces, and British Columbia.

Only nominations received before 15 January 1977 will be included in the list proposed to the membership by the nominating committee. However, names of the other candidates may be placed on the ballots by any two members submitting a nomination paper, signed by themselves and the nominee, to the secretarytreasurer before midnight of the first day of the annual meeting.

\title{
NOMINATIONS A LA DIRECTION DE L'ACSP
}

Selon les provinces de l'article viII, paragraphe 2, de la constitution, le comité de nomination invite les membres de l'Association canadienne de science politique à présenter des nominations au poste de président désigné, vice-président, et conseillers (6) du Bureau de direction, et au poste de membres (3) du comité de nomination. Les nominations doivent parvenir au secrétaire-trésorier (a/s Carleton University, Col. By Drive, Ottawa, Ont. K1S 5B6) avant le 15 janvier, 1977.

Les nominations devraient tenir compte d'une répartition géographique qui comprendrait les régions suivantes : les provinces de l'Atlantique, le Québec, l'Ontario, les provinces de l'ouest et la Colombie-Britannique.

Seules les nominations reçues avant le 15 janvier 1977 seront inclues dans la liste présentée aux membres par le comité de nomination. Cependant, le nom d'autres candidats pourra être ajouté à la liste des candidats par l'action conjointe de deux membres qui, à cet effet, devront remettre au secrétaire-trésorier, avant minuit du premier jour la réunion annuelle, un avis de nomination signé par le candidat et par eux-mêmes. 